\title{
Dose-specific effect of simvastatin on hypoxia-induced HIF-1a and BACE expression in Alzheimer's disease cybrid cells
}

\author{
Jin-Heon Jeong ${ }^{1}$, Kyu Sun Yum², Jun Young Chang ${ }^{3}$, Manho Kim', Jin-young Ahn', SangYun Kim³, \\ Paul A Lapchak ${ }^{6}$ and Moon-Ku Han ${ }^{3^{*}}$
}

\begin{abstract}
Background: Alzheimer's disease (AD) is associated with vascular risk factors; brain ischemia facilitates the pathogenesis of $A D$. Recent studies have suggested that the reduction of $A D$ risk with statin was achieved by decreased amyloidogenic amyloid precursor protein.

Methods: We used mitochondrial transgenic neuronal cell (cybrid) models to investigate changes in the levels of intracellular hypoxia inducible factor $1 \mathrm{a}(\mathrm{HIF-1a)}$ ) and $\beta$-site amyloid precursor protein cleaving enzyme (BACE) in the presence of simvastatin. Sporadic AD (SAD) and age-matched control (CTL) cybrids were exposed to $2 \% \mathrm{O}_{2}$ and incubated with $1 \mu \mathrm{M}$ or $10 \mu \mathrm{M}$ simvastatin.

Results: There was no significant difference between cell survival by 1 or $10 \mu \mathrm{M}$ simvastatin in both SAD and CTL cybrids. In the presence of $1 \mu \mathrm{M}$ simvastatin, intracellular levels of HIF-1a and BACE decreased by $40-70 \%$ in SAD, but not CTL cybrids. However, $10 \mu \mathrm{M}$ simvastatin increased HIF-1a and BACE expression in both cybrid models.

Conclusion: Our results suggest demonstrate differential dose-dependent effects of simvastatin on HIF-1a and BACE in cultured Alzheimer's disease cybrid cells.
\end{abstract}

Keywords: Alzheimer's disease, Cybrid cell, Statin, Hypoxia, HIF-1a, BACE

\section{Background}

Alzheimer's disease (AD) is a progressive neurodegenerative disorder that affects memory function; it is characterized by the formation of senile plaques composed of beta amyloid (A $\beta)$ [1]. Vascular risk factors such as hypertension and diabetes mellitus have an established association with $\mathrm{AD}$, and over $30 \%$ of $\mathrm{AD}$ patients show evidence of cerebral infarcts $[2,3]$. Brain ischemia contributes to the pathogenesis of $\mathrm{AD}[2,3]$, and the molecular link between hypoxia and $A \beta$ production is well established. Hypoxia increases expression of $\beta$-site amyloid precursor protein cleaving enzyme (BACE) via induction of hypoxia inducible factor $1 \alpha(\mathrm{HIF}-1 \alpha)$, resulting in increased $\beta$-secretase activity and $A \beta$ production [4-6].

\footnotetext{
* Correspondence: mkhan@snu.ac.kr

${ }^{3}$ Department of Neurology, College of Medicine, Seoul National University, Seoul National University Bundang Hospital, Seongnam, Korea

Full list of author information is available at the end of the article
}

Statins (HMG-CoA reductase inhibitor) have some utility in stroke prevention and studies have shown that statin administration can reduce the incidence of and improve functional outcomes after ischemic stroke [7]. The neuroprotective properties of statins have been demonstrated in models of cerebral ischemia [8]. Beyond their originally defined role in lowering cholesterol, statins have been used to manage neurodegenerative disorders such as vascular dementia and AD [9], because they can improve vascular integrity. Statins also alter HIF- $1 \alpha$ related gene expression by modulating DNA-binding activity [10]; HIF- $1 \alpha$ is essential to the cellular and systemic response to hypoxia [11]. Epidemiologists have found up to a $70 \%$ decreased risk of $\mathrm{AD}$ in people taking statins [12] and several studies have shown that statins reduce the production of $A \beta[13,14]$. The effects of statin differed according to dose; low-dose simvastatin decreases $A \beta$ production without increment of $A \beta$ release [15].

C Biomed Central

(c) 2015 Jeong et al. This is an Open Access article distributed under the terms of the Creative Commons Attribution License (http://creativecommons.org/licenses/by/4.0), which permits unrestricted use, distribution, and reproduction in any medium, provided the original work is properly credited. The Creative Commons Public Domain Dedication waiver (http:// creativecommons.org/publicdomain/zero/1.0/) applies to the data made available in this article, unless otherwise stated. 
Cytoplasmic hybrid (cybrid) cell models have been used to demonstrate the role of dysfunctional mitochondria in AD pathogenesis. Studies using this technique have shown that Sporadic AD (SAD) cybrids have increased intracellular and/or extracellular $A \beta$ levels that induce apoptotic neuronal death [16]. SAD cybrids also show increased accumulation of oxidative stress markers such as trans-4-hydroxy-2-nonenal adducts [17], which play an integral role in cellular toxicity. Cybrids are thus a good model for the study of mechanisms involved in cellular pathology. We used cybrids to investigate the changes in intracellular HIF-1 $\alpha$ and BACE levels in the presence of simvastatin under hypoxic conditions.

\section{Methods}

\section{Cell culture experiments}

Mitochondrial transgenic neuronal cells (cybrids) of SAD and age-matched controls (CTL) were used to investigate the effect of simvastatin on HIF- $1 \alpha$ and BACE expression under hypoxic conditions. We used established Alzheimer's disease cybrid models that were created by transferring mitochondria from a living $\mathrm{AD}$ patient and age-matched control donor into the mitochondrial DNA (mtDNA) free human neuroblastoma (SH-SY5Y) cells [16]. The cybrid cells obtained from the University of Virginia. The resulting cell lines differed only in the source of mtDNA that repopulated the cells, but otherwise had identical nuclear genetic and environmental backgrounds, allowing for the in vitro elucidation of mitochondrial genomic differences [17].

\section{In vitro hypoxia and simvastatin treatment}

Cultures were maintained in Dulbecco's Modified Eagle's Medium (DMEM) supplemented with $10 \%$ fetal bovine serum (FBS), $100 \mathrm{U}$ penicillin, and $0.1 \mathrm{mg} / \mathrm{mL}$ streptomycin at $37{ }^{\circ} \mathrm{C}$ under $5 \% \mathrm{CO}_{2} / 95 \% \mathrm{O}_{2}$ until reaching $70 \%$ confluence. After starving the cells with DMEM containing $0.2 \% \mathrm{FBS}$ for $24 \mathrm{~h}$, the cultures were placed in normoxic or hypoxic conditions with $1 \mu \mathrm{M}$ or $10 \mu \mathrm{M}$ simvastatin throughout the course of the experiments $(0-12 \mathrm{~h})$ [15]. Simvastatin was obtained from Chong Kun Dang Pharmaceutical Co., Ltd. (Seoul, South Korea). Treatments were performed in triplicate, and experiments were repeated three times.

All hypoxic ischemia experiments were performed with cultures incubated in a humidified hypoxic chamber. To induce hypoxia, the cultures were incubated in $93 \% \mathrm{~N}_{2} / 5 \% \mathrm{CO}_{2} / 2 \% \mathrm{O}_{2}$ at $37{ }^{\circ} \mathrm{C}$.

\section{Cell viability assay}

Cell viability was determined by MTT (3-[4,5-dimethylthiazol-2-yl]-2,5-diphenyl tetrazolium bromide) assay. A stock solution of MTT $(5 \mathrm{mg} / \mathrm{mL}$ in phosphate-buffered saline, $\mathrm{pH}$ 7.4) was freshly prepared, and the cells were incubated for $4 \mathrm{~h}$ at a final concentration of $1 \mathrm{mg} / \mathrm{mL}$. The samples on each plate were read on an ELISA reader with a reference wavelength of $570 \mathrm{~nm}$. The results are expressed as a percentage of absorbance at $490 \mathrm{~nm}$ directly proportional to the number of living cells following experimental hypoxia.

\section{HIF and BACE immunoassay}

For immunoblot analysis, cells cultured on $100 \mathrm{~mm}$ plates were washed with $4{ }^{\circ} \mathrm{C}$ phosphate-buffered saline (PBS) and collected by centrifugation. The cells were homogenized in lysis buffer $[100 \mathrm{mmol} / \mathrm{L} \mathrm{NaCl}, 10 \mathrm{mmol} / \mathrm{L}$ Tris (pH 7.5), $1 \mathrm{mmol} / \mathrm{L}$ EDTA] with freshly prepared protease inhibitors (1 mM phenylmethylsulfonyl fluoride). Protein concentrations were determined using the Bradford method (Bio-Rad, Richmond, CA). Protein extracts $(40 \mu \mathrm{g})$ were separated by $10 \%$ sodium dodecyl sulfatepolyacrylamide gel electrophoresis and transferred to a nitrocellulose membrane. The membranes were blocked in $5 \%$ nonfat skim milk in TBS $(0.15 \mathrm{M} \mathrm{NaCl}, 25 \mathrm{mM}$ Tris- $\mathrm{HCl}, 25 \mathrm{mM}$ Tris) for $2 \mathrm{~h}$, and then incubated at a 1:500 dilution overnight at $4{ }^{\circ} \mathrm{C}$ with anti-BACE (rabbit polyclonal antibodies, Millipore corporation) or antiHIF-1 $\alpha$ (mouse monoclonal antibodies, BD bioscience) antibodies. After washing 3 times in TBST (TBS + $0.5 \%$ Tween-20), the membrane was incubated with secondary antibody (anti-rabbit or anti-mouse) for $1 \mathrm{~h}$ at room temperature. Immunoreactive bands were detected by enhanced chemiluminescence with Kodak film. All experiments were repeated three times.

\section{Statistical analysis}

Graphical data represent the means $( \pm$ SE) of at least three independent experiments. Luminograms are representative of at least three experiments with similar results. Statistical analysis was performed by Student's $t$-test when appropriate. A P value of 0.05 was considered statistically significant in all cases.

\section{Ethics}

All the experiments were conducted at Seoul National University Bundang Hospital and the study was approved by the local ethics committee of the Seoul National University Bundang Hospital.

\section{Results}

Simvastatin did not reduce hypoxia- induced cell deaths

We analyzed the effect of simvastatin on cell viability under hypoxia. CTL and SAD cells showed reduced cell viability over $12 \mathrm{~h}$ hypoxic conditions $\left(2 \% \mathrm{O}_{2}\right)$. Between $0 \mathrm{~h}$ and $3 \mathrm{~h}$, viability was reduced to $50 \%$ of the control level, and after $12 \mathrm{~h}, 70 \%$ of the cells were dead. After treatment with simvastatin $(1 \mu \mathrm{M}$ and $10 \mu \mathrm{M})$, there was no difference in survival between the SAD and CTL cybrids (Fig. 1). 

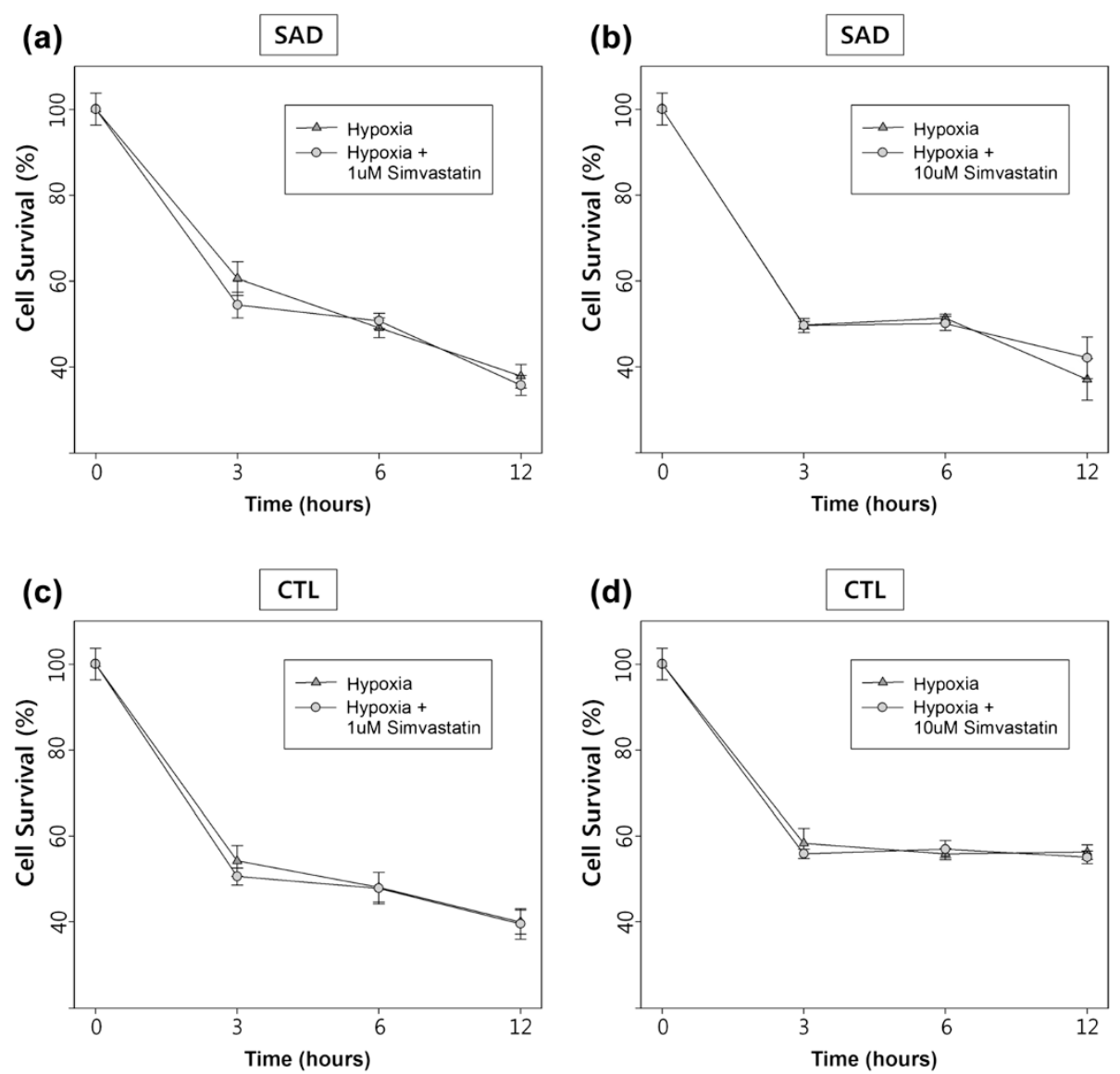

Fig. 1 The effect of simvastatin on cell survival. Cells were incubated with 1 or $10 \mu \mathrm{M}$ simvastatin under hypoxia. Cell viability was measured by MTT assay. ( $\mathbf{a}, \mathbf{b}, \mathbf{c}, \mathbf{d})$ Cell survival decreased over time. There were no significant difference between cell survival in both SAD and CTL cybrids ( $p>0.05)$. $X$-axis represents hypoxia duration; Y-axis represents mean percentage ( \pm SE) of cell survival comparing to the 0 time point. All experiments were repeated three times

\section{Low-dose simvastatin decreased HIF-1a and BACE expression in SAD cybrids}

In order to determine the effect of simvastatin on HIF-1 $\alpha$ mediated BACE expression, we used immunoassay. Hypoxia increased expression of HIF-1 $\alpha$ and BACE in both CTL and SAD cybrids (Figs. 2 and 3). HIF-1 $\alpha$ levels increased rapidly for the first $6 \mathrm{~h}$, and began to decrease at $12 \mathrm{~h}$. BACE levels gradually increased throughout the $12 \mathrm{~h}$ period. After treatment with $1 \mu \mathrm{M}$ simvastatin, HIF- $1 \alpha$ and BACE levels decreased in the SAD cybrids (Fig. 2a, 2b). HIF-1 $\alpha$ levels decreased by $70 \%(3 \mathrm{~h}), 40 \%(6 \mathrm{~h})$, and $40 \%(12 \mathrm{~h})$ with $1 \mu \mathrm{M}$ simvastatin $(" P<0.05)$ (Fig. $2 \mathrm{a})$. BACE levels decreased at $12 \mathrm{~h}(40 \%)$, but there was little change at $3 \mathrm{~h}(<10 \%)$ and $6 \mathrm{~h}$ (10 \%) (Fig. 2b). The reduction in HIF-1 $\alpha$ expression was prominent at $3 \mathrm{~h}$, and the reduction in BACE expression was pronounced at $12 \mathrm{~h}$.

In CTL cybrids, treatment with $1 \mu \mathrm{M}$ simvastatin did not significantly affect HIF- $1 \alpha$ and BACE expression (Fig. 2c, 2d).
High-dose simvastatin increased HIF-1a and BACE expression in SAD and CTL cybrids

Treatment with $10 \mu \mathrm{M}$ simvastatin increased expression of HIF- $1 \alpha$ and BACE (Fig. 3). HIF- $1 \alpha$ levels increased by up to $10 \%(3-12 \mathrm{~h})$ in SAD cybrids and $110-130 \%(3-12 \mathrm{~h})$ in CTL cybrids. The increase in HIF-1 $\alpha$ expression was significant at $6 \mathrm{~h}$ and $12 \mathrm{~h}$ in CTL cybrids, but the change was smaller in SAD cybrids. BACE levels increased by $20-40 \%$ (3-12 h) in SAD cybrids, and 20-40 \% (3-12 h) in CTL cybrids. BACE expression significantly increased at $6 \mathrm{~h}$ and $12 \mathrm{~h}$ in SAD cybrids, and at $3 \mathrm{~h}$ in CTL cybrids (" $p<0.05)$.

\section{Discussion}

This study investigated the changes in HIF- $1 \alpha$ and BACE levels in the presence of simvastatin under hypoxic conditions in AD cybrid cells. In SAD cybrids, HIF- $1 \alpha$ and BACE levels decreased by $40-70 \%$ with low-dose simvastatin; however, high-dose simvastatin increased the expression of HIF- $1 \alpha$ and BACE up to $130 \%$. A $\beta$ is derived from $\beta$-amyloid precursor protein by proteolytic cleavage 

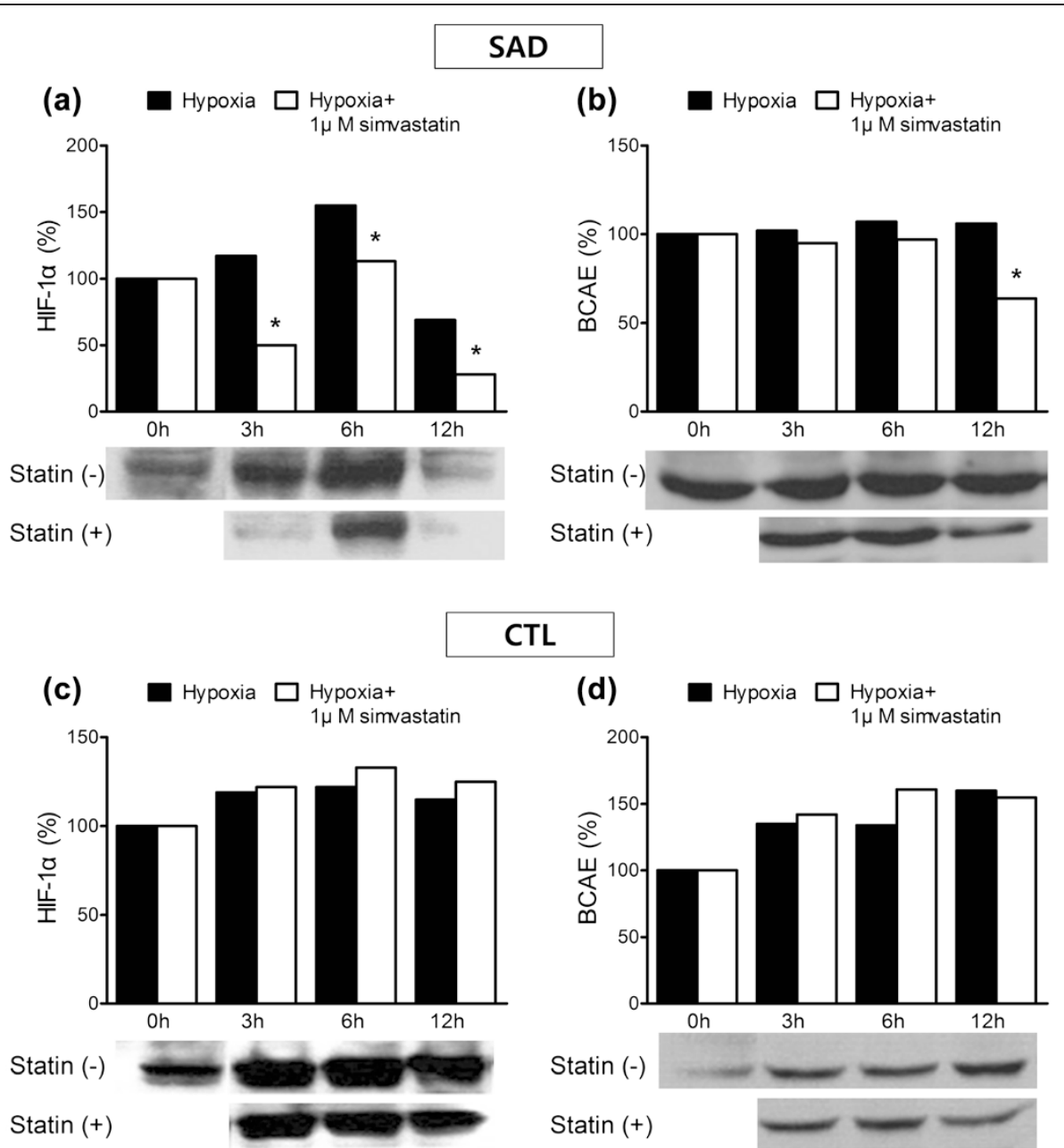

Fig. 2 The effect of low-dose simvastatin on HIF-1a and BACE expression. Cells were incubated with 0 and $1 \mu \mathrm{M}$ simvastatin under hypoxia. Intracellular HIF-1a and BACE levels were measured by western blotting. a In SAD cybrids, HIF-1a was significantly decreased at $3 \mathrm{~h}, 6 \mathrm{~h}$, and $12 \mathrm{~h}$ in the presence of $1 \mu \mathrm{M}$ simvastatin $\left({ }^{*} P<0.05\right)$. b In SAD cybrids, BACE significantly decreased at $12 \mathrm{~h}$ in the presence of $1 \mu \mathrm{M}$ simvastatin $\left({ }^{*} P<0.05\right)$. $\mathbf{c}, \mathbf{d}$ In $C T L$ cybrids, $1 \mu \mathrm{M}$ simvastatin did not influence HIF-1a and BACE expression. X-axis represents hypoxia duration; Y-axis represents percentage value from the immunoassay versus the 0 time point. All experiments were repeated three times

from $\beta$-secretase via induction of BACE [4-6]. Increased BACE activity and elevated insoluble $A \beta$ peptide have been shown in brain tissue of patients with $A D$, suggesting that abnormal BACE activity contributes to AD pathogenesis [5]. Stroke or ischemia gives rise to hypoxic conditions known to increase the incidence of $\mathrm{AD}$ and hypoxia increases transcription of BACE via overexpression of HIF- $1 \alpha[3,5]$. In this study, low-dose simvastatin reduced HIF- $1 \alpha$ mediated BACE production from hypoxic injury in SAD cybrids, but not in high-dose.

Other studies have shown the dose-dependent effects of statin on biochemical markers. High-dose simvastatin $(10 \mu \mathrm{M})$ increased $\mathrm{A} \beta$ release from HEK cells, but lowdose simvastatin $(1 \mu \mathrm{M})$ showed little difference [15]. One study demonstrated the dose-dependent effect of atorvastatin on endothelial cell migration and angiogenesis [18]. Low-dose statin promotes migration of mature endothelial cells and progenitor cells that contribute to vasculogenesis. However, high-dose statins block angiogenesis and migration by inducing endothelial cell apoptosis. In cortical neuronal cells, low-dose simvastatin $(100 \mathrm{nmol})$ protects against cytotoxcity by enhancing expression of $\mathrm{Bcl}-2$ mRNA [19]. Pre-incubation with low-dose simvastatin reduces $A \beta$ peptide-induced cell death in cortical and cerebellar neurons [20]. If in vitro experiments correctly reflect pathophysiological events that take place in the human brain, chronic low-dose statin administration may be therapeutically beneficial.

Cholesterol is an important factor in the regulation of $A \beta$ production. High-dose statins inhibit cholesterol synthesis, and low cellular cholesterol levels reduce $A \beta$ secretion [13, 14]. Low-dose statins preferentially inhibit isoprenoid biosynthesis $[21,22]$ and inhibition of $\beta$ secretase dimerization by low isoprenoid reduces $A \beta$ 

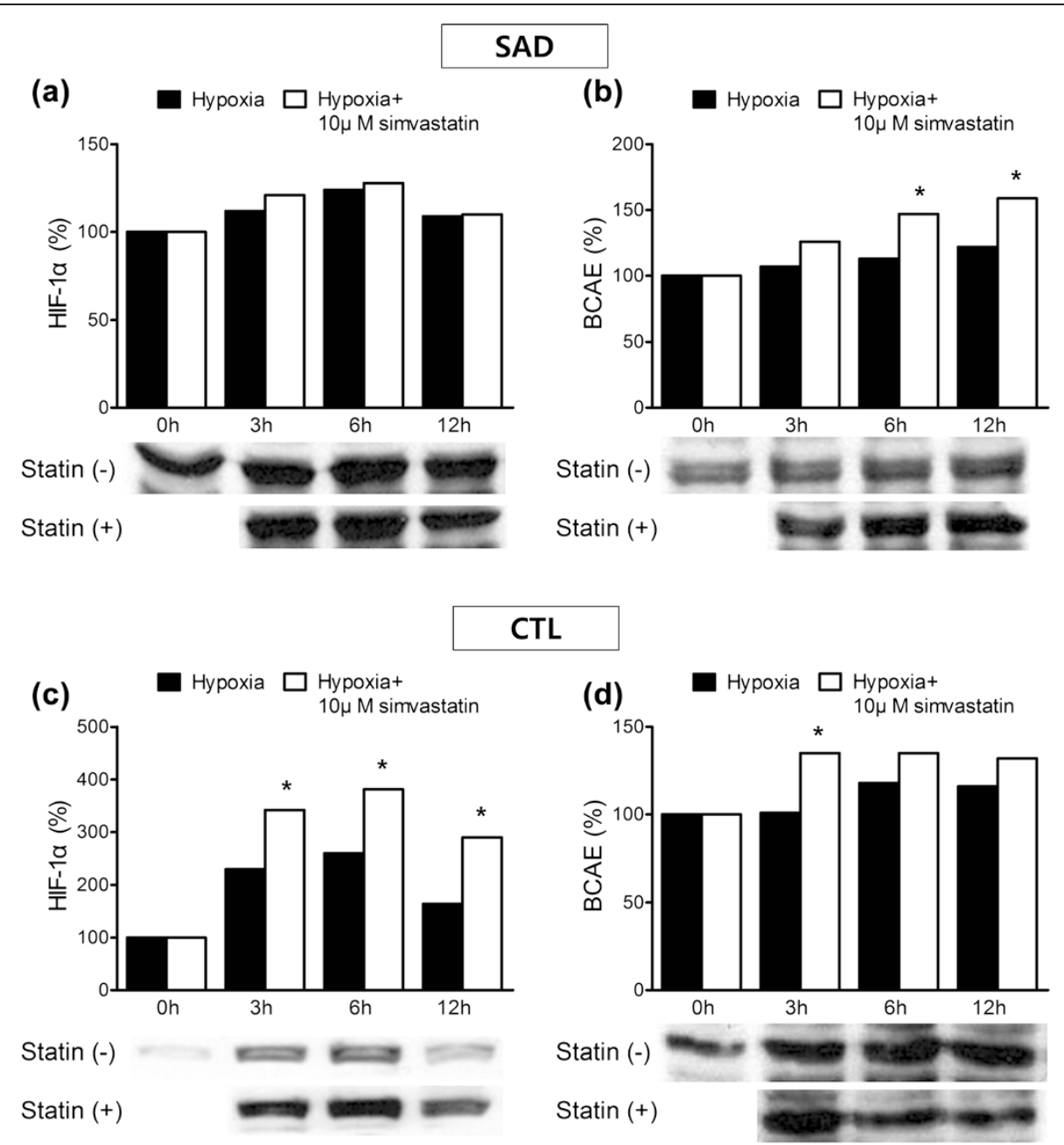

Fig. 3 The effect of high-dose simvastatin on expression of HIF-1 $a$ and BACE. Cells were incubated with 0 and $10 \mu M$ simvastatin under hypoxia. Intracellular HIF-1a and BACE levels were measured by western blotting. a In SAD cybrids, $10 \mu \mathrm{M}$ simvastatin did not influence HIF-1a. b In SAD cybrids, BACE significantly increased at $6 \mathrm{~h}$ and $12 \mathrm{~h}$ in the presence of $10 \mu \mathrm{M}$ simvastatin $\left({ }^{*} P<0.05\right)$. c $\mathrm{ln} \mathrm{CTL}, \mathrm{HIF}-1$ a significantly increased at $3 \mathrm{~h}, 6 \mathrm{~h}$, and $12 \mathrm{~h}$ in the presence of $10 \mu \mathrm{M}$ simvastatin $\left.{ }^{*} P<0.05\right)$. $\mathbf{d}$ In CTL, BACE significantly increased at $3 \mathrm{~h}$ in the presence of $10 \mu \mathrm{M}$ simvastatin $(* P<0.05)$. X-axis represents hypoxia duration; $Y$-axis represents represents percent values from the immunoassay versus the 0 time point. All experiments were repeated three times

production $[15,23]$. Statins also modulate the DNAbinding activity of HIF- $1 \alpha$ and simvastatin attenuates HIF-1 $\alpha$ expression in vascular smooth muscle cells $[10,23]$.

Several groups have reported the benefit of statins in the treatment of $\mathrm{AD}$. In patients with mild $\mathrm{AD}$, high-dose simvastatin $(80 \mathrm{mg} /$ day $)$ treatment reduced $A \beta$ levels in the cerebrospinal fluid (CSF) [24]. In addition, $20 \mathrm{mg}$ simvastatin reduced CSF levels of amyloid precursor protein in patients with $\mathrm{AD}$ [25]. Lovastatin (10-60 mg/day) produced a dose-dependent decrease in serum $A \beta$ in patients with elevated levels of low-density lipoprotein cholesterol [26]. These studies showed the benefit of statin treatment in reducing $A \beta$ production in humans, but differences between the types and doses of statin have not been satisfactorily defined.

Patients with $\mathrm{AD}$ are susceptible to chronic hypoxia $[2,27]$. Disrupted perfusion is present in the early phases of $\mathrm{AD}$ [2]; consequently, a reduction of oxygen delivery to the brain promotes mitochondrial dysfunction and apoptosis [17]. As expected, SAD cybrids derived from AD patients are also susceptible to chronic hypoxia. We used a cybrid cell model to evaluate mitochondrial dysfunction in AD patients under hypoxic conditions. Mitochondrial dysfunction in the presence of oxidative stress is intimately involved with $\mathrm{AD}$ pathophysiology. The mitochondrial electron chain acts as an oxygen sensor, releasing reactive oxygen species in response to hypoxia, 
thereby promoting oxidative stress, leading to cell death [28]. Mitochondrial dysfunction is observed in the platelets and lymphocytes of AD patients and their postmortem brain tissue [29].

Several studies have shown that statin activity on $A \beta$ production is mediated by BACE $[15,22,30]$. In vitro and in vivo studies have shown that overexpression of BACE elevates $A \beta$ production [31, 32]. This up-regulation of BACE and hypoxic stress are thought to have pathogenic relevance to neurodegeneration and dementia. Although we did not directly measure $A \beta, B A C E$ activity is estimated as an indirect biological marker of $A \beta$ production.

\section{Conclusions}

This study was designed to determine the effects of simvastatin on the expression of HIF- $1 \alpha$ and BACE in cybrid cells as possible important mediators of amyloid precursor protein processing. We demonstrated a dose-dependent differential response of simvastatin on HIF- $1 \alpha$ and BACE expression. While low-dose simvastatin reduced the expression of HIF- $1 \alpha$ and BACE under hypoxia in SAD cybrids, high-dose simvastatin increased the expression of both markers. Thus, our studies suggest the potential utility of therapeutic low-dose simvastatin regimen to control HIF- $1 \alpha$ and BACE expression, which may prevent beta amyloid production. Additional translational studies in transgenic mice are required to demonstrate beneficial effects of simvastatin on amyloid load and reversal of behavioral deficits prior to clinical studies in AD patients.

\section{Abbreviations \\ AD: Alzheimer's disease; A : beta amyloid; BACE: $\beta$-site amyloid precursor protein cleaving enzyme; CTL: age matched controls; DMEM: Dulbecco's Modified Eagle's Medium; FBS: fetal bovine serum; HIF-1a: hypoxia inducible factor 1a; mtDNA: mitochondrial DNA; MTT: 3-[4,5-dimethylthiazol-2-yl]-2, 5-diphenyl tetrazolium bromide; PBS: phosphate-buffered saline; SAD: sporadic Alzheimer's disease..}

\section{Competing interests}

Paul A Lapchak is the Editor-in-chief of the Journal of Neurology \& Neurophysiology and Associate Editor of Translational Stroke Research. The other authors have nothing to disclose.

\section{Authors' contributions}

MK, JA, SK, PAL and MH designed and supervised the experiments. JJ, KY and JC performed all the experiments. JJ, KY, JC and MH analyzed the data and drafted the manuscript. MK, JA, SK and PAL contribute to the data analysis and editing manuscript. All of authors read and approved the final manuscript.

\section{Acknowledgments}

We thank Kyeng-Mi Kwon for excellent technical assistance.

\section{Author details}

'Department of Neurology, College of Medicine, Chungbuk National University, Chungbuk National University Hospital, Cheongju, Korea. ${ }^{2}$ Department of Neurology, College of Medicine, Konyang University, Konyang University Hospital, Daejeon, Korea. ${ }^{3}$ Department of Neurology, College of Medicine, Seoul National University, Seoul National University Bundang Hospital, Seongnam, Korea. ${ }^{4}$ Department of Neurology, College of Medicine, Seoul National University, Seoul National University Hospital, Seoul, Korea. ${ }^{5}$ Department of Neurology, Seoul Medical Center, Seoul, Korea.
${ }^{6}$ Departments of Neurology and Neurosurgery, Cedars-Sinai Medical Center, Los Angeles, USA.

Received: 26 February 2015 Accepted: 22 July 2015

Published online: 31 July 2015

\section{References}

1. Braak H, Braak E. Evolution of the neuropathology of Alzheimer's disease. Acta Neurol Scand Suppl. 1996;165:3-12.

2. de la Torre JC. Alzheimer disease as a vascular disorder: nosological evidence. Stroke. 2002;33:1152-62.

3. Koistinaho M, Koistinaho J. Interactions between Alzheimer's disease and cerebral ischemia-focus on inflammation. Brain Res Brain Res Rev. 2005;48:240-50.

4. Sun X, He G, Qing H, Zhou W, Dobie F, Cai F, et al. Hypoxia facilitates Alzheimer's disease pathogenesis by up-regulating BACE1 gene expression. Proc Natl Acad Sci U S A. 2006;103:18727-32.

5. Zhang X, Zhou K, Wang R, Cui J, Lipton SA, Liao FF, et al. Hypoxia-inducible factor 1alpha (HIF-1alpha)-mediated hypoxia increases BACE1 expression and beta-amyloid generation. J Biol Chem. 2007;282:10873-80.

6. Guglielmotto M, Aragno M, Autelli R, Giliberto L, Novo E, Colombatto S, et al. The up-regulation of BACE1 mediated by hypoxia and ischemic injury: role of oxidative stress and HIF1alpha. J Neurochem. 2009;108:1045-56.

7. Lakhan SE, Bagchi S, Hofer M. Statins and clinical outcome of acute ischemic stroke: a systematic review. Int Arch Med. 2010;3:22.

8. Stepien K, Tomaszewski M, Czuczwar SJ. Neuroprotective properties of statins. Pharmacol Rep. 2005;57:561-9.

9. Wang Q, Yan J, Chen X, Li J, Yang Y, Weng J, et al. Statins: multiple neuroprotective mechanisms in neurodegenerative diseases. Exp Neurol. 2011;230:27-34.

10. Dichtl W, Dulak J, Frick M, Alber HF, Schwarzacher SP, Ares MP, et al. HMG-CoA reductase inhibitors regulate inflammatory transcription factors in human endothelial and vascular smooth muscle cells. Arterioscler Thromb Vasc Biol. 2003;23:58-63.

11. Ogunshola OO, Antoniou X. Contribution of hypoxia to Alzheimer's disease: is HIF-1alpha a mediator of neurodegeneration? Cell Mol Life Sci. 2009;66:3555-63.

12. Jick H, Zornberg GL, Jick SS, Seshadri S, Drachman DA. Statins and the risk of dementia. Lancet. 2000;356:1627-31.

13. Sidera $C$, Parsons $R$, Austen $B$. The regulation of beta-secretase by cholesterol and statins in Alzheimer's disease. J Neurol Sci. 2005;229-230:269-73.

14. Cole SL, Grudzien A, Manhart IO, Kelly BL, Oakley H, Vassar R. Statins cause intracellular accumulation of amyloid precursor protein, beta-secretase-cleaved fragments, and amyloid beta-peptide via an isoprenoid-dependent mechanism. J Biol Chem. 2005;280:18755-70.

15. Parsons RB, Price GC, Farrant JK, Subramaniam D, Adeagbo-Sheikh J, Austen BM. Statins inhibit the dimerization of beta-secretase via both isoprenoid- and cholesterol-mediated mechanisms. Biochem J. 2006;399:205-14.

16. Onyango IG, Tuttle JB, Bennett Jr JP. Altered intracellular signaling and reduced viability of Alzheimer's disease neuronal cybrids is reproduced by beta-amyloid peptide acting through receptor for advanced glycation end products (RAGE). Mol Cell Neurosci. 2005;29:333-43.

17. Onyango IG, Bennett Jr JP, Tuttle JB. Endogenous oxidative stress in sporadic Alzheimer's disease neuronal cybrids reduces viability by increasing apoptosis through pro-death signaling pathways and is mimicked by oxidant exposure of control cybrids. Neurobiol Dis. 2005;19:312-22.

18. Urbich C, Dernbach E, Zeiher AM, Dimmeler S. Double-edged role of statins in angiogenesis signaling. Circ Res. 2002;90:737-44.

19. Johnson-Anuna LN, Eckert GP, Franke C, Igbavboa U, Muller WE, Wood WG. Simvastatin protects neurons from cytotoxicity by up-regulating $\mathrm{BCl}-2$ mRNA and protein. J Neurochem. 2007;101:77-86.

20. Bate $C$, Williams $A$. Squalestatin protects neurons and reduces the activation of cytoplasmic phospholipase A2 by Abeta(1-42). Neuropharmacology. 2007;53:222-31.

21. Bellosta S, Via D, Canavesi M, Pfister P, Fumagalli R, Paoletti R, et al. HMG-CoA reductase inhibitors reduce MMP-9 secretion by macrophages. Arterioscler Thromb Vasc Biol. 1998;18:1671-8. 
22. Frears ER, Stephens DJ, Walters CE, Davies H, Austen BM. The role of cholesterol in the biosynthesis of beta-amyloid. Neuroreport. 1999;10:1699-705.

23. Wilson SH, Herrmann J, Lerman LO, Holmes Jr DR, Napoli C, Ritman EL, et al. Simvastatin preserves the structure of coronary adventitial vasa vasorum in experimental hypercholesterolemia independent of lipid lowering. Circulation. 2002;105:415-8.

24. Simons M, Schwarzler F, Lutjohann D, von Bergmann K, Beyreuther K, Dichgans J, et al. Treatment with simvastatin in normocholesterolemic patients with Alzheimer's disease: A 26-week randomized, placebocontrolled, double-blind trial. Ann Neurol. 2002;52:346-50.

25. Sjogren M, Gustafsson K, Syversen S, Olsson A, Edman A, Davidsson P, et al. Treatment with simvastatin in patients with Alzheimer's disease lowers both alpha- and beta-cleaved amyloid precursor protein. Dement Geriatr Cogn Disord. 2003;16:25-30.

26. Friedhoff LT, Cullen El, Geoghagen NS, Buxbaum JD. Treatment with controlled-release lovastatin decreases serum concentrations of human beta-amyloid (A beta) peptide. Int J Neuropsychopharmacol. 2001;4:127-30.

27. Zhu X, Smith MA, Perry G, Aliev G. Mitochondrial failures in Alzheimer's disease. Am J Alzheimers Dis Other Demen. 2004;19:345-52.

28. Chandel NS, Maltepe E, Goldwasser E, Mathieu CE, Simon MC, Schumacker PT. Mitochondrial reactive oxygen species trigger hypoxia-induced transcription. Proc Natl Acad Sci U S A. 1998;95:11715-20.

29. Chaturvedi RK, Beal MF. Mitochondrial approaches for neuroprotection. Ann N Y Acad Sci. 2008;1147:395-412.

30. Parsons RB, Farrant JK, Price GC, Subramaniam D, Austen BM. Regulation of the lipidation of beta-secretase by statins. Biochem Soc Trans. 2007:35:577-82.

31. Tamagno E, Bardini P, Obbili A, Vitali A, Borghi R, Zaccheo D, et al. Oxidative stress increases expression and activity of BACE in NT2 neurons. Neurobiol Dis. 2002;10:279-88.

32. Kao SC, Krichevsky AM, Kosik KS, Tsai LH. BACE1 suppression by RNA interference in primary cortical neurons. J Biol Chem. 2004;279:1942-9.

\section{Submit your next manuscript to BioMed Central and take full advantage of:}

- Convenient online submission

- Thorough peer review

- No space constraints or color figure charges

- Immediate publication on acceptance

- Inclusion in PubMed, CAS, Scopus and Google Scholar

- Research which is freely available for redistribution 